\title{
Netrin-1 Is a Chemorepellent for Oligodendrocyte Precursor Cells in the Embryonic Spinal Cord
}

\author{
Andrew A. Jarjour, Colleen Manitt, Simon W. Moore, Katherine M. Thompson, Sung-Joo Yuh, and Timothy E. Kennedy \\ Centre for Neuronal Survival, Montreal Neurological Institute, McGill University, Montreal, Quebec, Canada H3A 2B4
}

\begin{abstract}
Netrin-1, secreted by floor plate cells, orients axon extension in relation to the ventral midline of the embryonic spinal cord. Oligodendrocyte precursor (OP) cells are born close to the ventral midline and migrate away from the floor plate. Here we show that OP cells, identified by expression of the platelet-derived growth factor $\alpha$ receptor, express the netrin receptors $d c c$ and $u n c 5 h 1$ but do not express netrin-1. Using a microchemotaxis assay, we demonstrate that migrating OPs are repelled by a gradient of netrin-1 in vitro. Furthermore, application of netrin- 1 to OPs in vitro triggers retraction of OP processes. In the absence of netrin-1 or Deleted in Colorectal Cancer (DCC) function in vivo, fewer OP cells migrate from the ventral to the dorsal embryonic spinal cord, consistent with netrin-1 acting as a repellent. In addition to their role regulating cell movement, DCC and UNC-5 homologs have been suggested to function as proapoptotic dependence receptors, triggering cell death in the absence of netrin-1. In contrast, we report no evidence of increased OP cell death in vivo or in vitro in the absence of either netrin-1 or DCC. These findings indicate that netrin-1 is a repellent cue for migrating OPs in the embryonic spinal cord.
\end{abstract}

Key words: oligodendrocyte precursor cell; cell migration; netrin-1; DCC; unc5h1; embryonic spinal cord; multiple sclerosis; apoptosis; dependence receptor

\section{Introduction}

During the development of the CNS, many neural cell types migrate great distances to reach their final destinations. Although neuronal migration has been studied extensively, the cues that direct the migration of oligodendrocyte precursors (OPs) are not well understood. Several factors that influence OP motility in vitro have been identified. Basic fibroblast growth factor (bFGF or FGF-2) and the platelet-derived growth factor (PDGF)-A chain are soluble chemoattractants for OPs (Armstrong et al., 1990; Milner et al., 1996; Simpson and Armstrong, 1999), and reduced numbers of OPs and oligodendrocytes have been found in PDGF-A knock-out mice (Fruttiger et al., 1999). However, because PDGF-A is also a mitogen for OPs (Noble et al., 1988; Calver et al., 1998), this phenotype may be caused by deficient OP migration, deficient OP proliferation, or both. Substrates of the extracellular matrix proteins laminin, fibronectin, or vitronectin promote OP migration (Milner et al., 1996), whereas tenascin C and collagen are nonpermissive substrates for migrating OPs (Kiernan et al., 1996; Milner et al., 1996). The rate of OP migration increases in tenascin-C null mice, but tenascin $\mathrm{C}$ does not appear to direct OP cell migration (Garcion et al., 2001). Sugimoto et al. (2001) have provided evidence that both semaphorin-3A (Sema3A) and netrin-1 are chemorepellents for OP cells migrating from explants of newborn rat optic nerve. In

Received Aug. 20, 2002; revised Jan. 13, 2003; accepted Jan. 14, 2003.

This work was supported by the Multiple Sclerosis Society of Canada and the Canadian Institutes of Health Research (CIHR). A.A.J. was supported by Fonds pour la Formation de Chercheurs et l'Aide à la Recherche du Québec and Multiple Sclerosis Society of Canada studentships. T.E.K. is a CIHR Scholar. We thank Adriana Di Polo, Cecilia Flores, Alan Peterson, and Peter Braun for comments on this manuscript and Mireille Bouchard, Talan Basmascioglu, Michel Gravel, and Laurence Simard-Emond for technical assistance.

Correspondence should be addressed to Timothy E. Kennedy, Centre for Neuronal Survival, Montreal Neurological Institute, McGill University, 3801 University Street, Montreal, Quebec, Canada H3A 2B4. E-mail: timothy.kennedy@mcgill.ca. Copyright $\odot 2003$ Society for Neuroscience $\quad$ 0270-6474/03/233735-10\$15.00/0 contrast, using a similar in vitro assay, Spassky et al. (2002) conclude that netrin- 1 attracts OP cells migrating from explants of embryonic optic nerve. Spassky et al. (2002) also provide evidence for Sema3F attracting migrating OPs, and, in agreement with Sugimoto et al. (2001), that Sema3A is a chemorepellent for these cells. Although these experiments address OP migration in vitro, whether these cues direct $\mathrm{OP}$ migration in vivo is not clear.

In the embryonic spinal cord, OPs originate in the ventral ventricular zone, at two foci located on either side of the midline, slightly dorsal to the floor plate (Pringle and Richardson, 1993; Yu et al., 1994; Ono et al., 1995; Orentas and Miller, 1996). Beginning at $\sim$ E12.5 in the mouse, OPs disperse throughout the developing spinal cord, migrating away from the ventral midline (Calver et al., 1998). This trajectory suggests that cues produced by floor plate cells may repel migrating OP cells.

We postulated that netrin-1 might function as a repellent for OP cells in the embryonic spinal cord. Netrin-1 is produced at the ventral midline of the embryonic neural tube, where it repels some types of migrating axons and attracts others (Kennedy et al., 1994; Colamarino and Tessier-Lavigne, 1995; Varela-Echavarria et al., 1997). Netrin-1 also directs the circumferential migration of neuronal precursor cells (Varela-Echavarria et al., 1997; Przyborski et al., 1998; Alcantara et al., 2000; Hamasaki et al., 2001). Here we show that netrin-1 is expressed by floor plate cells as OP cells migrate away from the ventral midline of the developing spinal cord. A netrin receptor complex composed of Deleted in Colorectal Cancer (DCC) and an UNC-5 homolog (UNC5H) mediates the repellent response to netrin-1 (Hong et al., 1999). We report that both $d c c$ and unc5hl are expressed by migrating OP cells in the embryonic spinal cord. To test the hypothesis that netrin-1 might influence OP motility, we used an in vitro microchemotaxis assay and found that a gradient of netrin-1 repels the migration of cultured OP cells. Application of netrin-1 to OP cells 
in vitro caused the retraction of $\mathrm{OP}$ processes, consistent with a repellent function. Furthermore, we report that the distribution of OP cells is disrupted in the spinal cords of mouse embryos lacking DCC or netrin-1. Importantly, the change in cell distribution occurs without a change in cell number, indicating that the absence of netrin-1 or DCC does not affect cell survival. These findings indicate that netrin-1 functions as a repellent guidance cue for OP cell migration in the embryonic spinal cord.

\section{Materials and Methods}

Animals and oligodendrocyte precursor cell culture. Sprague Dawley rat pups and pregnant BALB/c mice were obtained from Charles River Canada (Quebec, Canada). Mice heterozygous for netrin-1 or DCC function were obtained from Marc Tessier-Lavigne (Stanford University, Stanford, CA) and Robert Weinberg (Harvard University, Cambridge, MA), respectively. All procedures with animals were performed in accordance with the Canadian Council on Animal Care guidelines for the use of animals in research. Oligodendrocyte precursor cells were obtained from mixed glial cultures derived from the cerebral cortices of postnatal day 0 rat pups, as described previously (Armstrong, 1998).

Antibodies, immunocytochemistry, and immunohistochemical quantification. The following antibodies were used: monoclonal anti-NG2 (Chemicon, Temecula, CA), anti-DCC intracellular domain (G97-449), anti-DCC function blocking antibody $\left(\mathrm{DCC}_{\mathrm{FB}}\right.$, AF5; Calbiochem, La Jolla, CA), polyclonal anti-PDGF $\alpha$ receptor (PDGF $\alpha$ R, C-20; Santa Cruz Biotechnology, Santa Cruz, CA), and anti-netrin PN2 (Manitt et al., 2001). A2B5 hybridoma was provided by V. W. Yong (University of Calgary, Calgary, Canada).

For live labeling with $\mathrm{A} 2 \mathrm{~B} 5$, cells were incubated for $30 \mathrm{~min}$ at $4^{\circ} \mathrm{C}$ with hybridoma supernatant. Unbound antibody was washed away with DMEM. Cells were then washed with PBS, fixed with $4 \%$ paraformaldehyde (PFA), permeabilized with PBS containing $0.25 \%$ Triton X-100, and blocked with $3 \%$ heat-inactivated horse serum (HS)-1\% bovine serum albumin- $0.1 \%$ Triton X-100. Cells were then incubated with antiDCC or anti-netrin PN2 diluted in blocking solution. NG2 labeling was similarly performed on fixed cells without the live labeling step. Primary antibodies were detected with secondary antibodies coupled to Cy3 or Alexa 488 (Molecular Probes, Eugene, OR). Nuclei were stained with Hoechst dye.

For immunohistochemical analyses, netrin-1 or DCC heterozygous mice were crossed, and embryonic day 15 (E15) embryos were obtained (plug date was designated as E1). Embryos were frozen in 2-methyl butane (Fisher Scientific, Houston, TX) chilled in liquid nitrogen and then mounted individually in optimal cutting temperature compound (Tissue Tek; Sakura Finetek, Torrance, CA); next, $6 \mu \mathrm{m}$ cryostat sections of the spinal brachial enlargement were cut, mounted onto slides (Superfrost Plus; Fisher Scientific), and fixed by immersion in 4\% PFA, 15\% picric acid, $\mathrm{pH} 8.5$, in PBS (45 min at room temperature). The sections were rinsed in PBS, permeabilized with $0.5 \%$ Triton X-100 in PBS, and rinsed in PBS. To enhance antigenicity, sections were immersed in boiling PBS in a microwave oven for $11 \mathrm{~min}$, cooled, and blocked (5\% heatinactivated HS and 1\% BSA in PBS for $1 \mathrm{hr}$ at room temperature). Sections were then incubated with anti-PDGF $\alpha \mathrm{R}$ (1:1000) in blocking solution (overnight, $4^{\circ} \mathrm{C}$ ) and visualized using Alexa 488-conjugated secondary antibody. Sections were stained with Hoechst dye to visualize nuclei. Fluorescence was visualized using a Zeiss (Toronto, Canada) Axiovert 100 microscope, a Magnafire CCD camera (Optronics, Goleta, CA), and Northern Eclipse Software (Empix Imaging, Ontario, Canada). To analyze the distribution of OPs, each spinal cord section was photographed in four quadrants using a $20 \times$ objective. The four images were assembled into a single image of a complete spinal cord using Photoshop (Adobe Systems, San Jose, CA). The length of the dorsoventral axis was measured along the midline from the top of the roof plate to the base of the ventral commissure, and each cord was divided into thirds. A cell was counted only if anti-PDGF $\alpha$ R staining encircled a blue Hoechst-stained nucleus. Because of this criterion, fewer cells were counted in this analysis per section of cord relative to previous studies using PDGF $\alpha$ R mRNA in situ hybridization (Calver et al., 1998). Three sections were counted per embryo. Nonadjacent sections were counted to avoid counting the same cell more than once.

Transfilter microchemotaxis assay. OP-enriched cell suspensions were plated at a density of $1.25 \times 10^{5} \mathrm{cells} / \mathrm{ml}$ on poly-D-lysine-coated polycarbonate transwell culture inserts $(6.5 \mathrm{~mm}$ diameter with $8 \mu \mathrm{m}$ pore size; Corning, Corning, NY). One hundred microliters of cell suspension were used per filter, and the filters were placed in the wells of a 24 well tissue culture plate over $600 \mu \mathrm{l}$ of medium. Oligodendrocyte defined medium (OLDEM) was the base medium used for all assay conditions (DMEM, $5 \mu \mathrm{g} / \mathrm{ml}$ insulin, $100 \mu \mathrm{g} / \mathrm{ml}$ transferrin, $30 \mathrm{~nm}$ sodium selenite, $30 \mathrm{~nm}$ triiodothyronine, $6.3 \mathrm{ng} / \mathrm{ml}$ progesterone, $16 \mu \mathrm{g} / \mathrm{ml}$ putrescine, $100 \mathrm{U} / \mathrm{ml}$ penicillin, $100 \mu \mathrm{g} / \mathrm{ml}$ streptomycin, and $2 \mathrm{~mm}$ glutamax). Cells were allowed to migrate for $16 \mathrm{hr}$ at $37^{\circ} \mathrm{C}$, cells on the upper side of the filter were then scraped off, and the cells attached to the lower side of the filter were fixed with $4 \%$ PFA/0.1\% glutaraldehyde (30 min, room temperature). Filters were then rinsed with PBS, and cell nuclei were stained with Hoechst dye. Cell nuclei were imaged using epifluorescence. For each transwell assay, a single image of the filter was captured using a $4 \times$ objective, and nuclei were counted using Northern Eclipse software. Where pooled results are presented, the value referred to as "percentage migration versus control" (see Fig. $3 C$ ) for a given trial represents the number of cells that migrated in that condition expressed as a percentage of the mean number of cells migrating in control conditions.

Analysis of OP morphology. Dissociated OP cells were plated in OLDEM at a density of $2.5 \times 10^{4}$ cells/well in an 8 well plastic chamber slide precoated with poly-D-lysine. Cells were maintained in culture overnight, and the medium was then replaced with either fresh OLDEM (as a control) or OLDEM plus the factors being tested. After incubations of $30 \mathrm{~min}, 2 \mathrm{hr}$, or $16 \mathrm{hr}$, the cells were fixed and labeled with rhodamineconjugated phalloidin, anti-PDGF $\alpha \mathrm{R}$ (visualized using Alexa 488conjugated secondary antibody), and Hoechst as described above. The surface area, length of longest process, and number of major processes of PDGF $\alpha$ R-positive OPs were measured using rhodamine-phalloidin staining and Northern Eclipse software. Surface area corresponds to the two-dimensional surface area of the entire OP cell, including the cell body and all processes. The length of the longest process is the measurement from the base of the longest process to its tip. A major process refers to a terminal process whose length exceeded the maximum diameter of the cell body.

(3-(4,5-Dimethylthiazol-2-yl)-2,5-diphenyltetrazolium bromide assay. Dissociated OP cells were plated in OLDEM at a density of $1 \times 10^{4}$ cells/well in a 96 well tissue culture plate precoated with poly-D-lysine. Cells were grown in culture for $16 \mathrm{hr}$, followed by 1 additional hour in the presence of $0.5 \mathrm{mg} / \mathrm{ml} \mathrm{3-(4,5-dimethylthiazol-2-yl)-2,5-diphenyltetra-}$ zolium bromide (MTT; Sigma, St. Louis, MO). The medium was then aspirated, and the cells were dissolved in isopropanol (100 $\mu 1 /$ well). Absorbance of the converted dye $(\Delta \mathrm{OD})$ was measured at $570 \mathrm{~nm}$, with background subtraction at $630 \mathrm{~nm}$ (Denizot and Lang, 1986).

Statistical analyses. All comparisons were performed by ANOVA with Fisher's least significant difference post hoc test using Systat software (SPSS, Chicago, IL).

In situ hybridization. Sense and antisense cRNA probe pairs corresponding to netrin-1 (Manitt et al., 2001), dcc (Keino-Masu et al., 1996), unc5h1 and unc5h2 (Leonardo et al., 1997), and unc5h3 (Ackerman et al., 1997) were used. Cryostat sections of E15 mouse spinal cord were cut and fixed, and synthesis of digoxigenin (DIG)-labeled probes and hybridization were performed as described previously (Manitt et al., 2001). For in situ hybridization analysis of expression in vitro, OP cells were cultured using Lab-Tek chamber slides (Fisher Scientific) and fixed with 4\% PFA. Hybridization was performed overnight at $57^{\circ} \mathrm{C}$ (netrin-1), $57^{\circ} \mathrm{C}($ dcc $), 57^{\circ} \mathrm{C}$ (unc5h1), $60^{\circ} \mathrm{C}$ (unc5h2), and $57^{\circ} \mathrm{C}$ (unc5h3), followed by a stringent wash in $2 \times \mathrm{SSC}$ for $1 \mathrm{hr}$ at $65^{\circ} \mathrm{C}$. Slides were blocked $(0.5 \%$ blocking powder in $1 \times$ PBS; NEN, Boston, MA) for $30 \mathrm{~min}$ at room temperature. Hybridization was detected using a peroxidase-coupled antibody against DIG (Roche, Quebec, Canada). Incubation with anti-PDGF $\alpha$ R was performed during this step. In situ signals were amplified using the TSAIndirect Tyramide Signal Amplification kit (NEN) and visualized 

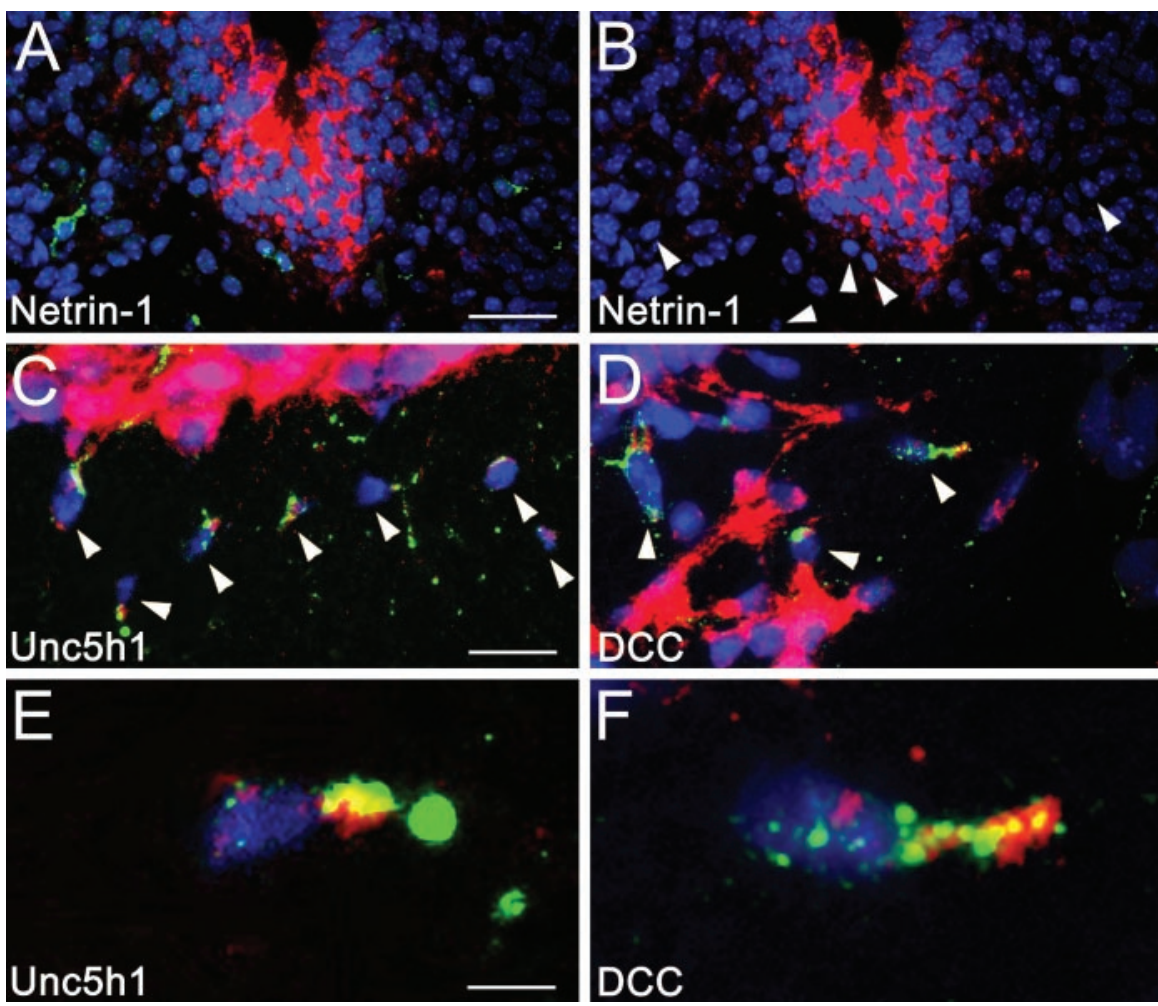

Figure 1. Oligodendrocyte precursors express dcc and unc $5 \mathrm{~h} 1$ but not netrin- 1 in vivo. Double-label in situ hybridization immunohistochemical analyses of coronal sections of E15 mouse spinal cord. Cell nuclei are stained blue with Hoechst dye. $A, B$, In situ hybridization identifies netrin-1-expressing floor plate cells (red). $B$ illustrates that the PDGF $\alpha$ R-immunopositive OPs in $A$ (green) do not express netrin-1. $C$ and $D$ show ventral spinal cord white matter and motoneurons at the edge of the gray matter. ( shows that PDGF $\alpha$ Rimmunopositive OPs ( green) express unc5h1 (red, in situ hybridization). E presents a fourfold magnification of one cell from C, illustrating double-labeling. D shows that PDGF $\alpha$ R-immunopositive OPs ( green) express dec (red, in situ hybridization). F depicts a fourfold magnification of one cell from D, illustrating double-labeling. No in situ hybridization signal was detected in PDGF $\alpha$ R-positive OPs ( green) using either the unc $5 h 1$ or the dec control sense hybridization probes (data not shown). Arrowheads in (and Dindicate double-labeled cells. The large PDGF $\alpha$ R-negative dcc-and unc $5 h 1$-positive cells in the gray matter are motoneurons. $A, B, 20 \times$ objective magnification; $C-F, 40 \times$ objective magnification. Scale bars: $A, B, 40 \mu \mathrm{m} ; C, D, 20 \mu \mathrm{m} ; E, F, 5 \mu \mathrm{m}$.

usingAlexa 594-conjugated streptavidin. Alexa 488-conjugated anti-rabbit IgG secondary antibody was used to visualize $\operatorname{PDGF} \alpha \mathrm{R}$ immunostaining.

\section{Results}

Netrin-1 is expressed at the ventral midline of the developing spinal cord during oligodendrocyte precursor migration In the embryonic spinal cord, OP cells are born in the ventricular zone just dorsal to the floor plate. These cells then migrate away to populate all regions of the cord (Pringle and Richardson, 1993; Yu et al., 1994; Ono et al., 1995; Orentas and Miller, 1996; DiersFenger et al., 2001). OP cells first appear in the embryonic mouse spinal cord at $\sim$ E12.5 and are distributed throughout the mouse brachial spinal cord by E15 (Pringle and Richardson, 1993; Calver et al., 1998). Netrin-1 is known to be expressed in the floor plate and ventral neuroepithelium of the E11.5 spinal cord (Serafini et al., 1996), but expression had not been examined later in development during OP cell migration. Using in situ hybridization analysis, we show that at E15, floor plate cells continue to express netrin-1 as OPs migrate through the neuroepithelium (Fig. 1A). Double labeling with an antibody against the PDGF $\alpha$ R, a marker specific for OP cells in the embryonic spinal cord, indicated that OPs do not express detectable levels of netrin-1 at E15 (Fig. 1A,B). Thus, expression of netrin-1 is temporally and spatially consistent with it having a role as an OP repellent.
Oligodendrocyte precursor cells express the netrin receptors $d c c$ and $u n c 5 h 1$ but not $u n c 5 h 2$ or unc $5 h 3$ in the E15 mouse spinal cord

DCC and UNC-5 homolog family members mediate the chemorepellent response of migrating neurons and axons to netrin-1 (Hedgecock et al., 1990; Hamelin et al., 1993; Przyborski et al., 1998; Hong et al., 1999; Goldowitz et al., 2000; Hamasaki et al., 2001; Keleman and Dickson, 2001). By labeling OP cells with anti-PDGF $\alpha \mathrm{R}$ in combination with in situ hybridization analysis, we investigated the expression of $d c c, u n c 5 h 1, u n c 5 h 2$, and $u n c 5 h 3$ by OPs in E15 spinal cord. Dcc and unc5h1 expression was detected in most if not all PDGF $\alpha$ R-positive OPs (Fig. $1 C-F$ ), supporting the hypothesis that these cells could respond to netrin-1. Unc5h2 and unc 5 h 3 expression was not detected in oligodendrocyte precursors at E15 (data not shown).

\section{Netrin-1 repels migrating \\ oligodendrocyte precursors in vitro}

To directly test the hypothesis that netrin-1 repels OP migration, cultures enriched for OP cells were prepared from the cerebral cortices of newborn rat brain as described previously (Armstrong, 1998). OP cells were identified using the A2B5 monoclonal antibody (Raff et al., 1983), polyclonal antibodies against NG2 (Stallcup and Beasley, 1987), or polyclonal antibodies against PDGF $\alpha$ R, all markers of OPs but not mature oligodendrocytes. Double labeling with these markers and either antibodies against netrin or DCC, or in situ hybridization for unc-5 homolog expression, was performed $24 \mathrm{hr}$ after plating OP cells. These findings indicated that under these conditions in vitro, all OP cells express DCC (Fig. $2 A, B$ ) and $u n c 5 h 1$ (Fig. 2C,D) but not netrin-1 (Fig. 2E). These results are consistent with our findings in the E15 spinal cord (Fig. 1).

We then determined whether netrin-1 influences OP migration using a transfilter microchemotaxis assay (Falk et al., 1980), an established method of analyzing OP cell motility (Armstrong et al., 1990; Simpson and Armstrong, 1999; Frost et al., 2000). Cells were plated onto the top surface of a polycarbonate filter containing pores $8 \mu \mathrm{m}$ in diameter that was suspended in the well of a tissue culture plate (Fig. $3 A$ ). Putative tropic factors can be tested by adding them to the medium beneath the filter, to the cell suspension before plating on top of the filter, or to both the top and bottom compartments. Cells migrating into a pore from the top of the filter can be challenged with an increasing gradient of the putative cue (cue on bottom), a decreasing gradient of the cue (cue on top), or an equal concentration of the cue on both sides (cue on top and bottom). Cells initially adhere to the upper surface of the filter. During migration, either spontaneously or in response to an added factor, some cells enter a pore and move to the lower side of the filter. At the end of the assay, which lasts 16 $\mathrm{hr}$, cells that remain on the upper side of the filter are scraped off 

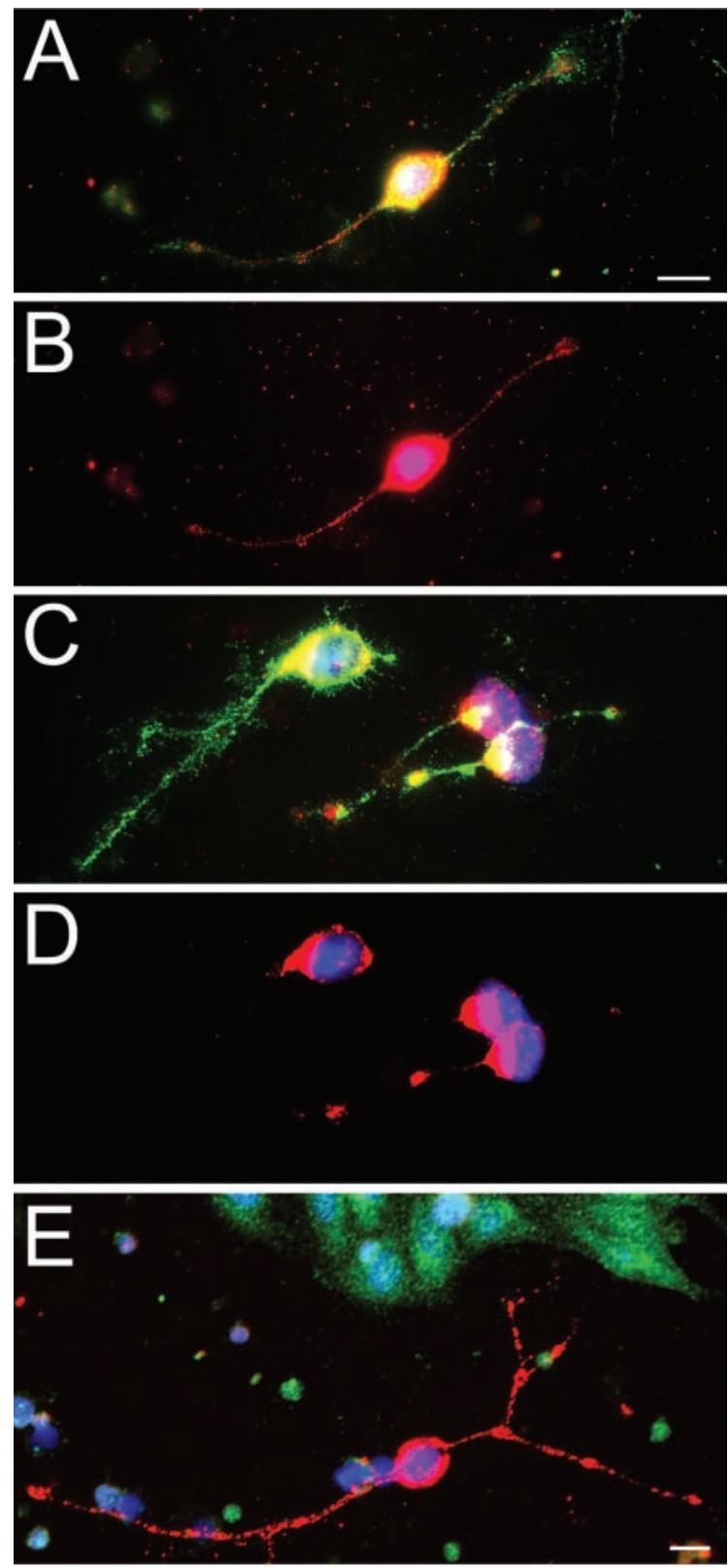

Figure 2. Oligodendrocyte precursors express $D C C$ and unc 5 h 1 but not netrin- 1 in vitro. $A$, OPs coimmunolabel with antibodies against the OP marker NG2 ( green) and the netrin receptor $D C C$ (red). $B$ illustrates the same cell as in A, showing only the DCC immunostaining (red) and Hoechst staining (blue). ( shows cells double-labeled with anti-PDGF $\alpha$ R (green) and with unc $5 \mathrm{~h} 1$ antisense RNA probes (red). D illustrates the same cell as in C, showing only the unc $5 \mathrm{~h} 1$ antisense signal. The corresponding unc $5 \mathrm{~h} 1$ sense RNA probe produced no signal (data not shown). E illustrates that OPs immunolabeled with the A2B5 monoclonal antibody (red) in a mixed glial culture are not labeled by an antibody against netrin-1 ( green). A-D, $100 \times$ objective magnification; $E, 40 \times$ objective magnification. Scale bar, $10 \mu \mathrm{m}$.

and the cells that have migrated to the lower side of the filter are fixed in place, stained, and counted. An attractant in the bottom chamber enhances migration from the top to the bottom of the filter. Conversely, a repellent cue in the lower chamber will reduce migration from the top to the bottom. A cue that has a kinetic effect will similarly influence migration regardless of being placed in the bottom chamber, top chamber, or both chambers.

Figure $3 B$ presents data from a single representative trial using the microchemotaxis assay. In the absence of any added cue,
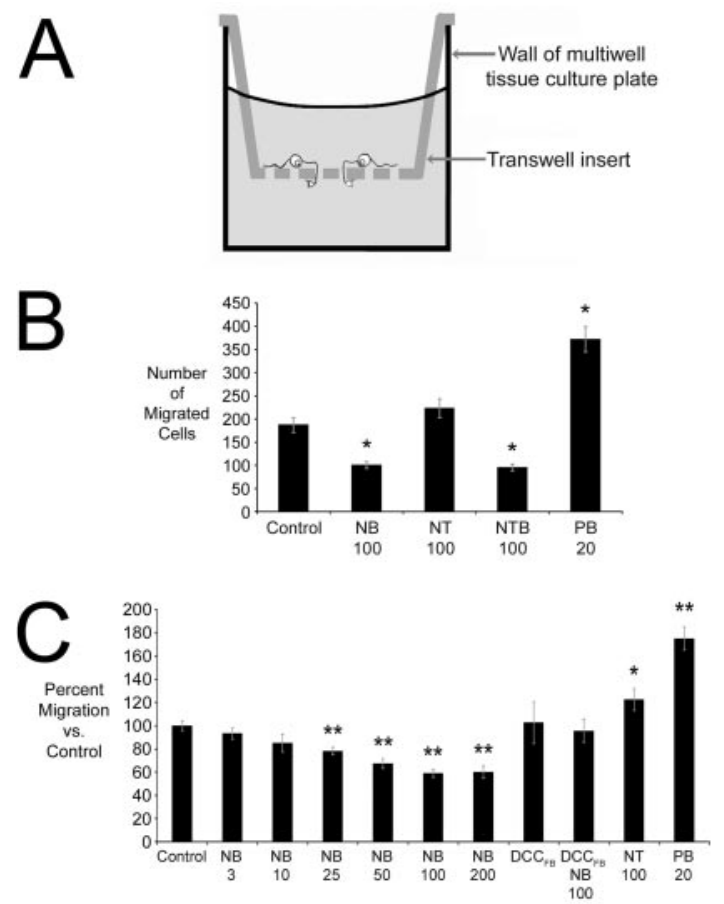

D
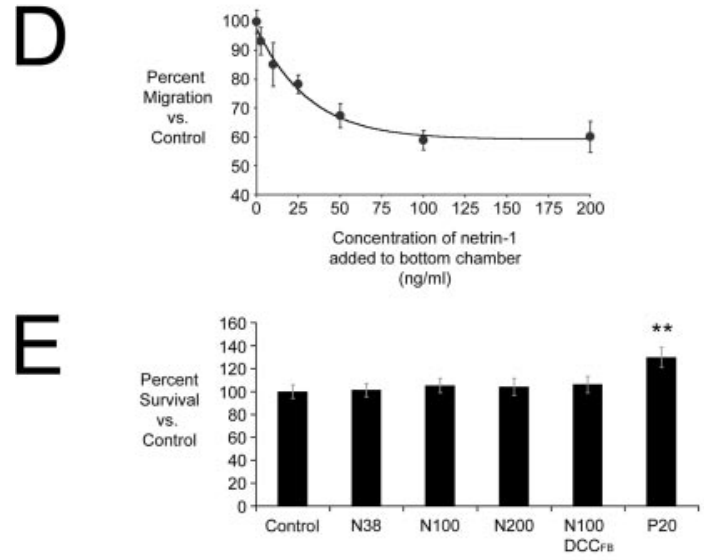

Figure 3. Netrin-1 is a chemorepellent for oligodendrocyte precursor cells in vitro. A, Illustration of the transfilter microchemotaxis assay. $B-D$, Netrin-1 repels $O P$ cells. $B$ shows the data from one representative trial of this experiment. Netrin- $1(100 \mathrm{ng} / \mathrm{ml})$ in the bottom compartment (NB 100) significantly reduced cell migration compared with control. Increased migration to the bottom chamber was seen when $100 \mathrm{ng} / \mathrm{ml}$ netrin- 1 was added to the top compartment (NT 100; B, C). The OP chemoattractant PDGF-AA ( $20 \mathrm{ng} / \mathrm{ml}$, bottom) was used as a positive control ( $P B$ 20). For each condition shown in $B, n=4$ wells per condition. ( presents results pooled from multiple experimental trials and expressed as a percentage of control. Increasing concentrations of netrin-1 (3-200 ng/ml, NB 3-NB 200) produce a graded increase in the repellent action of netrin-1. Addition of the DCC function blocking antibody $(2.7 \mu \mathrm{g} / \mathrm{ml})$ to the top and bottom chambers blocked the repellent action of netrin- 1 in the bottom chamber $\left(D C C_{F B} N B\right.$ 100). In the presence of $D C C_{F B}$ without added netrin-1, the same number of cells migrated as did in controls. In $C, n=22$ for controls; $n=8$ for NB 3, NB 10, NB25, NB 50, NB200, $D C C_{F B}, D_{C C}$ NB 100, and NT 100; $n=16$ for NB 100; and $n=21$ for PB 20. D, Analysis of the results presented in C indicated that $\sim 20 \mathrm{ng} / \mathrm{ml}$ netrin-1 produced a half-maximal repellent effect of netrin-1. E, The MTT assay indicated that application of netrin-1 at 0, 38 (N38), 100 (N100), or $200(N 200) \mathrm{ng} / \mathrm{ml}$ for $16 \mathrm{hr}$ does not affect OP survival $(n=6)$. Addition of DCC $\mathrm{FB}_{\mathrm{B}}$ with $100 \mathrm{ng} / \mathrm{ml}$ netrin-1 also had no effect. PDGF-AA, an established mitogen for OP cells, resulted in an increased number of OPs after $16 \mathrm{hr}$. Values shown are means \pm SEM. ${ }^{*} p<0.05$; ${ }^{* *} p<0.005$.

$187 \pm 16$ (mean \pm SEM per $4 \times$ field) OP cells spontaneously migrated to the bottom of the filter. PDGF-AA $(20 \mathrm{ng} / \mathrm{ml})$, a known OP cell chemoattractant, increased migration $(372 \pm 25$ cells) when added to the bottom compartment. In contrast, when 

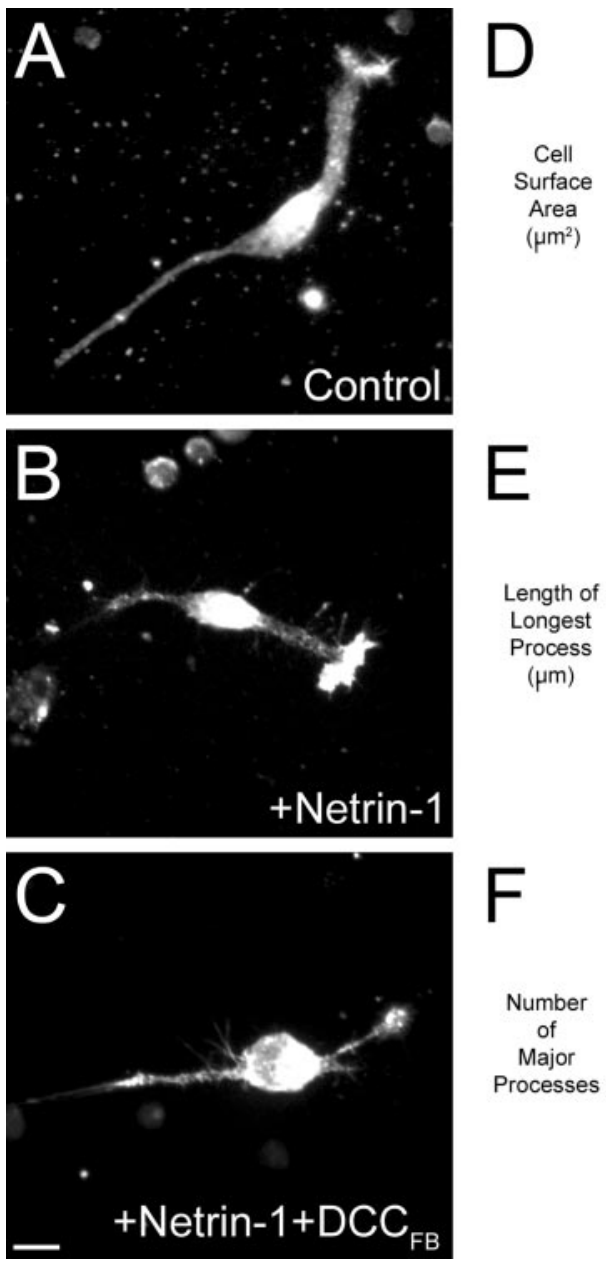
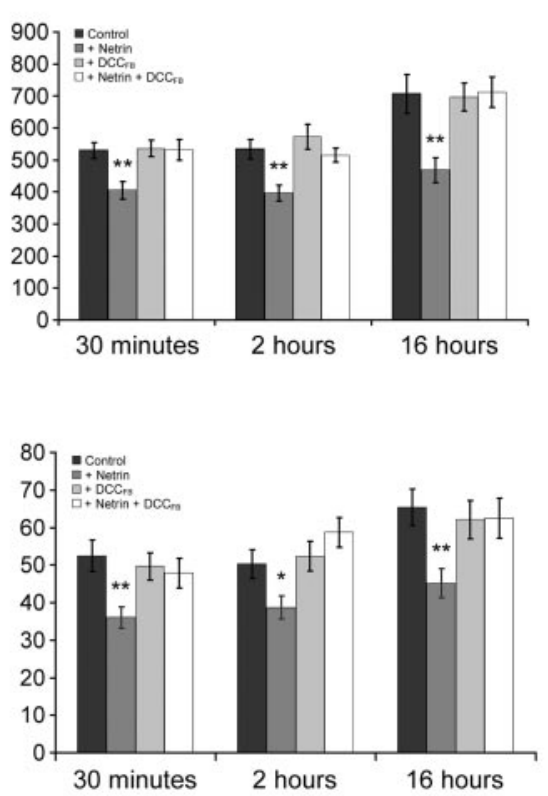

Figure 4. Retraction of OP processes induced by netrin-1. OP cultures were exposed to netrin-1, $D C C_{F B}$, or both netrin- 1 and $D C C_{F B}$ for $30 \mathrm{~min}, 2 \mathrm{hr}$, or $16 \mathrm{hr}$; fixed; and then stained for PDGF $\alpha$ R immunoreactivity and F-actin using rhodamine-coupled phalloidin. Phalloidin staining is shown in $A-C$. Cell surface area, length of longest process, and number of major processes were then quantified. $A-C$, Images of a control cell $(A)$ and cells exposed to netrin- $1(B)$ or netrin- 1 and $D C C_{F B}(C)$ for 30 min. The cells illustrated in $A-C$ have morphologies corresponding to the mean values shown in $D-F$ at the 30 min time point. Exposure of OP cells to netrin-1 for $30 \mathrm{~min}, 2 \mathrm{hr}$, or $16 \mathrm{hr}$ results in decreased mean cellular surface area $(D)$, length of the longest process $(E)$, and number of major processes $(F)$. Results obtained after incubation with $D C C_{F B}$ or coincubation of OPs with netrin-1 and DCC $C_{F B}$ did not differ significantly from controls. Values shown are means \pm SEM. ${ }^{*} p<0.05 ;{ }^{* *} p<0.005$. Objective magnification is $40 \times$. Scale bar, $10 \mu \mathrm{m}$.

OPs were challenged with $100 \mathrm{ng} / \mathrm{ml}$ netrin- 1 in the bottom compartment, migration decreased significantly (100 \pm 7 cells $)$. Addition of $100 \mathrm{ng} / \mathrm{ml}$ netrin-1 to the top compartment caused an increase in the number of cells migrating to the lower side of the filter $(223 \pm 21$ cells) (Fig. $3 B)$. When the results from multiple experimental trials were pooled (Fig. $3 C$ ), the increase in the number of cells migrating away from netrin-1 in the top compartment was found to be significant. Interestingly, when OPs were exposed to netrin-1 $(100 \mathrm{ng} / \mathrm{ml})$ added to both the top and bottom compartments (Fig. $3 B$ ), migration was reduced (95 \pm 8 cells) to a level not significantly different from that obtained with netrin-1 in the lower chamber alone. Immunostaining the cells plated on the top of the filter or the cells that migrated to the lower side of the filter demonstrated in both cases that $\sim 90 \%$ of the cells present were A2B5- or PDGF $\alpha$ R-positive (data not shown).

DCC contributes to mediating both attractant and repellent responses of neuronal growth cones to netrin-1 (Hong et al., 1999). To determine whether DCC is required for the repellent response of OP cells to netrin-1, OP cells were challenged with ne- trin- 1 in the lower chamber in the presence of a DCC function blocking antibody added to the top and bottom chambers $(2.7 \mu \mathrm{g} / \mathrm{ml}$ $\left.\mathrm{DCC}_{\mathrm{FB}}\right)$. Addition of $\mathrm{DCC}_{\mathrm{FB}}$ blocked the response to netrin-1, producing migration not significantly different from controls (Fig. $3 C)$.

We performed a dose-response analysis of the repellent action of netrin-1 using the transfilter migration assay. Cells were challenged with increasing concentrations of netrin-1, from 3 to $200 \mathrm{ng} / \mathrm{ml}$, added to the bottom chamber. Increasing concentrations of netrin- 1 resulted in fewer cells migrating across the filter (Fig. 3C). These values were best fit using a sigmoidal curve, and the $\mathrm{EC}_{50}$ for the repellent response of OP cells to netrin-1 was determined to be $\sim 20 \mathrm{ng} / \mathrm{ml}$ (Fig. 3D).

Netrin-1 has been proposed to have trophic effects (Mehlen et al., 1998; Forcet et al., 2001; Llambi et al., 2001) in addition to its well documented function as a tropic guidance cue. This raised the possibility that netrin-1 might influence transfilter migration through an effect on cell survival and not cell motility. We directly tested whether the presence or absence of netrin-1 influences the survival or proliferation of OP cells in vitro. We determined whether netrin- 1 influences OP survival or proliferation over a period of $16 \mathrm{hr}$ in culture, the duration of the migration assay, using MTT, as described previously (Denizot and Lang, 1986; Richter-Landsberg and Vollgraf, 1998; Pang et al., 2000). Quantification of the amount of metabolized MTT indicated that there was no difference between cells cultured without netrin- 1 and cells cultured with 38,100 , or $200 \mathrm{ng} / \mathrm{ml}$ netrin-1 or with $100 \mathrm{ng} / \mathrm{ml}$ netrin-1 and $2.7 \mu \mathrm{g} / \mathrm{ml} \mathrm{DCC}_{\mathrm{FB}}$ (Fig. $3 E$ ). These observations indicated that the presence or absence of netrin-1 does not affect the survival of these cells. In contrast, increased MTT conversion was detected in the presence of $20 \mathrm{ng} / \mathrm{ml}$ PDGF-AA (Fig. 3E). However, the $\sim 30 \%$ increase in dye production is not sufficient to account for the $\sim 75 \%$ increase in the number of cells detected on the underside of the filter at the end of the migration assay, consistent with PDGF being both a mitogen and a chemoattractant for OPs, as described previously (Noble et al., 1988; Armstrong et al., 1990; Milner et al., 1996; Calver et al., 1998; Simpson and Armstrong, 1999).

\section{Netrin-1 induces retraction of oligodendrocyte precursor cell processes}

Partial collapse of the cytoskeleton has been proposed to contribute to the turning response made by axonal growth cones to repellent guidance cues (Luo et al., 1993). To test the hypothesis that the repellent action of netrin-1 might trigger cytoskeletal collapse and process retraction, OPs were incubated in vitro with $100 \mathrm{ng} / \mathrm{ml}$ netrin-1 for $30 \mathrm{~min}, 2 \mathrm{hr}$, and $16 \mathrm{hr}$. OPs were then labeled with an antibody against PDGF $\alpha \mathrm{R}$ and for filamentous 
actin (F-actin) using rhodamine-coupled phalloidin. Addition of netrin- 1 caused a rapid and persistent decrease in OP surface area, process length, and process number at all time points. Addition of $2.7 \mu \mathrm{g} / \mathrm{ml} \mathrm{DCC} \mathrm{FB}_{\mathrm{F}}$ blocked the effect of netrin-1 at all time points examined. Application of $\mathrm{DCC}_{\mathrm{FB}}$ alone had no effect (Fig. 4; supplemental Table 1, available at www.jneurosci.org).

\section{Aberrant distribution of oligodendrocyte precursors in mice lacking netrin-1 or DCC}

To determine whether netrin- 1 contributes to directing OP migration in vivo, we examined the distribution of OP cells in E15 mouse embryos lacking functional netrin-1 or DCC. Although the optic nerve has been widely used as a model system to study oligodendrocyte development, in netrin-1 or DCC knock-out mice, the axons of retinal ganglion cell neurons do not enter the optic nerve, producing optic nerve hypoplasia (Deiner et al., 1997). We therefore focused our analysis of the distribution of OP cells in vivo on the E15 spinal cord. Heterozygous netrin-1 or DCC mice were crossed, producing litters containing wild-type, heterozygote, and homozygous loss-of-function embryos. Quantitative comparisons were performed within litters to maintain a precise age match between embryos.

Because development of the oligodendroglial lineage progresses along a rostrocaudal gradient in the spinal cord (Foran and Peterson, 1992; Hajihosseini et al., 1996), tissue sections were collected exclusively from the brachial enlargement. OPs were detected with antiPDGF $\alpha$ R. For quantification, the image of each cross section of the spinal cord was divided into dorsal, medial, and ventral thirds along the dorsoventral axis (Fig. 5A). A cell was counted only if antiPDGF $\alpha$ R staining encircled a blue Hoechst-stained nucleus (Fig. $5 B$ ). This analysis indicated that in embryos homozygous for loss of netrin-1 or DCC function, significantly fewer OP cells were present in the dorsal third of the spinal cord. A corresponding increase was found in the number of cells present in the ventral third of the embryonic spinal cord in the absence of netrin-1 or DCC function (Figs. 6, 7; supplemental Table 2, available at www.jneurosci.org). Importantly, the total OP cell number in sections of homozygous netrin-1 or DCC loss-of-function embryos was not significantly different from their heterozygote or wild-type littermates (Fig. 7B,D). To age match the embryos as precisely as possible, the data presented in Figure 7 and Table 2 are restricted to embryos derived from a single litter. The same total number of $\mathrm{PDGF} \alpha \mathrm{R}$-positive cells was not always found in E15 spinal cords when compared between litters, likely reflecting the lack of a precise age match. However, analysis of multiple litters always revealed the phenotype reported in Figure 7 and Table 2. These results indicate that the absence of netrin-1 or DCC function produces a dramatic change in the distribution of these cells, consistent with DCC being required to mediate a repellent response of OP cells to netrin-1.

\section{Discussion}

Netrins are a family of secreted proteins that function as tropic guidance cues directing cell and axon migration. We have reported recently that netrin-1 is expressed by mature myelinating oligodendroglia in the adult spinal cord (Manitt et al., 2001). This prompted us to investigate the possibility that netrin-1 might contribute to oligodendrocyte development. Here, we show that migrating OP cells in the embryonic spinal cord express $d c c$ and unc5h1. Furthermore, we report that in the absence of netrin-1 or DCC function, fewer OP cells are found in the dorsal embryonic spinal cord, with a corresponding increase in the ventral spinal cord. The total number of OP cells present in a section of spinal cord remains the same, supporting the conclusion that this phe-
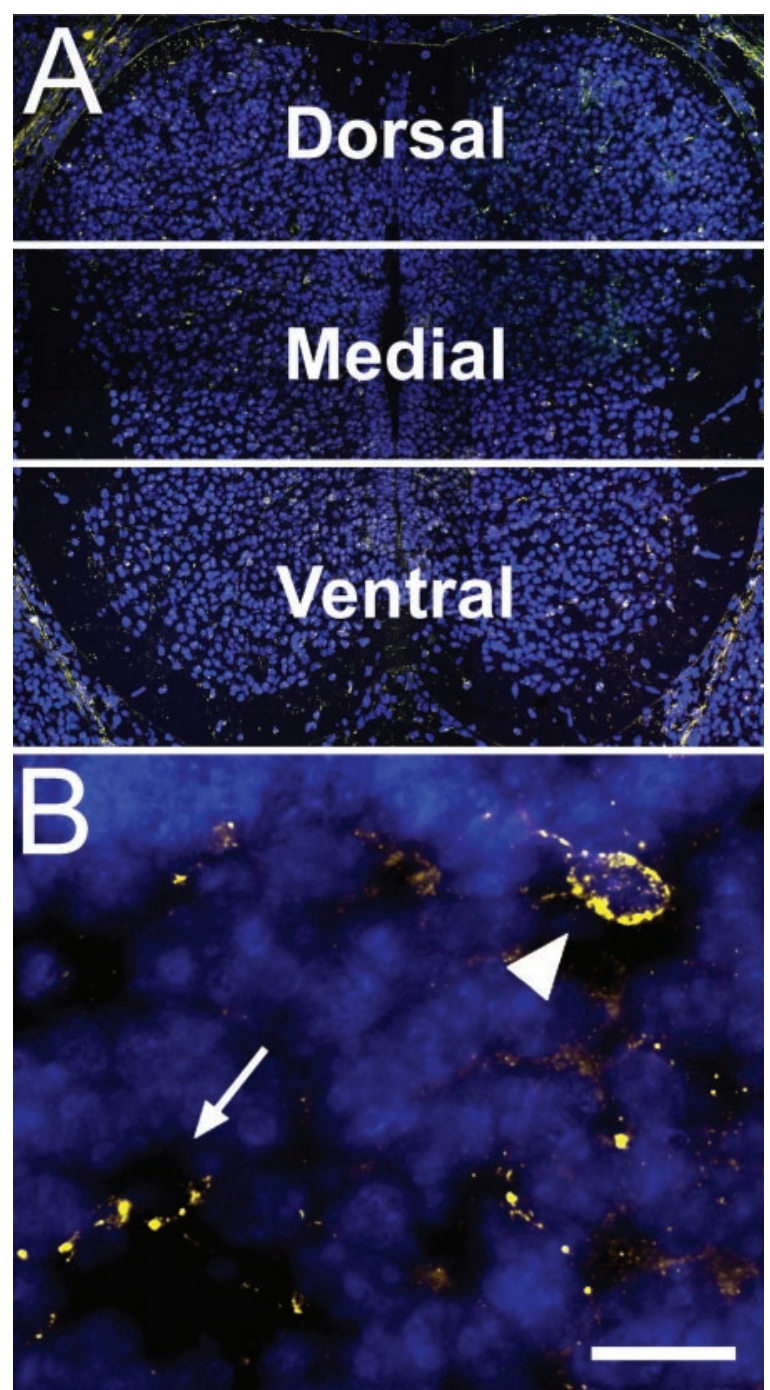

Figure 5. Analysis of OP cell distribution in E15 spinal cord. A, Coronal section of the brachial enlargement of an E15 spinal cord immunolabeled with anti-PDGF $\alpha$ R (yellow), and nuclei stained blue with Hoechst dye. For each section, four images were collected and tiled into a single image. The dorsoventral height of the cord was measured at the midline; the cord was divided into dorsal, medial, and ventral thirds; and the number of PDGF $\alpha$ R-positive OPs in each third was counted. Only cells with Hoechst-positive nuclei encircled by PDGF $\alpha$ R immunoreactivity ( $B$, arrowhead) were counted. Immunoreactivity not meeting this criterion ( $B$, arrow) was excluded. Scale bar, $20 \mu \mathrm{m}$.

notype is the result of disrupted OP migration and not the result of altered proliferation or cell death. The repellent response to netrin often involves both DCC and an UNC-5 homolog family member (Colavita and Culotti, 1998; Hong et al., 1999; Keleman and Dickson, 2001). Our analysis of the effect of loss of DCC function, either because of gene knock-out in vivo or because of using a function blocking antibody in vitro, indicates that OPs require DCC to be repelled by netrin-1.

In contrast, Spassky et al. (2002) have reported recently that an aggregate of cells expressing netrin-1 exerts a modest chemoattractive effect on OP cells migrating from explants of embryonic rat optic nerve in vitro. Several possibilities may account for the discrepancy between these results and our conclusion that netrin-1 functions as a repellent for OPs. Multiple lineages of OP cells have been described previously (Spassky et al., 1998; Fu et al., 2002), and it may be the case that OP cells migrating from ex- 

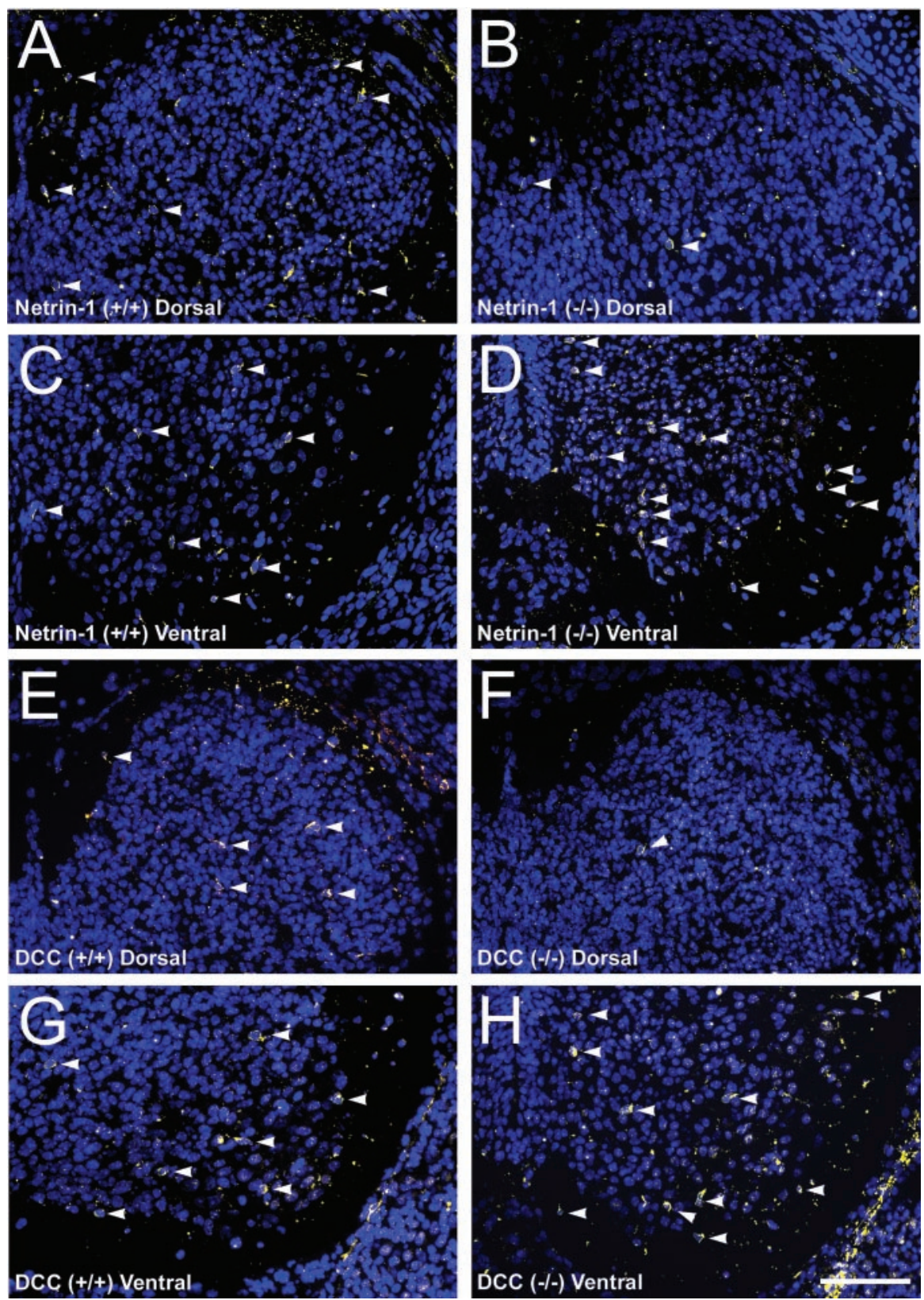

Figure 6. Distribution of OP cells in E15 spinal cord sections. The absence of netrin-1 or DCC function produces an aberrant distribution of OP cells in E15 spinal cord. Fewer PDGF $\alpha$ R-positive OP cells (arrowheads) were detected in the dorsal spinal cords of netrin-1 $(B)$ or DCC ( $F$ ) knock-out ( $-/-$ ) embryos compared with wild-type $(+/+)$ littermates $(A, E)$. Conversely, more OP cells were detected in the ventral spinal cords of netrin-1 $(D)$ or DCC $(H)$ knock-out $(-/-)$ embryos compared with their wild-type $(+/+)$ littermates $(C, G)$. $20 \times$ objective magnification. Scale bar, $100 \mu \mathrm{m}$.

plants of optic nerve are different from OP cells in the embryonic spinal cord. Second, cues presented with netrin-1 can influence the response to netrin-1 (Hopker et al., 1999). Such cues present in the optic nerve explant or secreted by the netrin-1-producing cells may switch the response of the OP cells to netrin-1 from repulsion to attraction. Importantly, the results of the transfilter migration assays reported here minimize the contributions of additional environmental factors by challenging OP cells with purified netrin-1 protein. In agreement with our findings, Sugimoto et al. (2001) have provided evidence that netrin-1 is a repellent cue for glial precursor cells, including OPs, migrating out of explants of newborn rat optic nerve. Spassky et al. (2002) suggest that the age of the explanted optic nerve may account for the discrepancy between these results, but this remains to be resolved. No direct evidence had been provided that netrin- 1 influences OP cell migration in vivo. Here, the results of our in vitro analysis are consistent our findings in vivo, indicating that netrin- 1 is a repellent for migrating OP cells in the embryonic spinal cord.

Relatively little is known about the migratory paths taken by OPs as they disperse throughout the developing spinal cord. Although radial glia may contribute to directing OPs laterally (Diers-Fenger et al., 2001), the ventrodorsal migration of OP cells is poorly understood. It was suggested that OPs might migrate dorsally along commissural axons (Miller, 1996); however, the absence of migrating streams of OPs along these axons argues against this (Miller et al., 1997; Calver et al., 1998). Alternatively, it has been proposed that OPs might be directed by cues that either attract them dorsally or repel them from the ventral embryonic spinal cord (Miller et al., 1997). Our finding that netrin-1 repels OP migration in vitro supports the conclusion that a repellent action of netrin-1 directs migrating OP cells into the dorsal embryonic spinal cord.

\section{Loss of DCC or netrin-1 function does} not induce OP cell death

Both DCC and UNC-5 homologs have been suggested to function as proapoptotic dependence receptors, causing cell death in the absence of netrin-1 (Mehlen et al., 1998; Forcet et al., 2001; Llambi et al., 2001). Convincing evidence, however, has not been provided that cells expressing physiologically relevant levels of netrin receptors die, either in vitro or in vivo, as a result of the absence of netrin. We show that OP cells express $d c c$ and $u n c 5 h 1$ but not netrin-1. The absence of netrin-1 or DCC caused a defect in migration, but no effect on cell survival was observed in vivo or in vitro, indicating that neither DCC nor UNC5H1 functions as a proapoptotic dependence receptor in these cells.

\section{Tropism, repulsion, and collapse}

Using the transfilter microchemotaxis assay, we found that netrin-1 placed in the bottom chamber reduced the number of OPs migrating to the lower side of the filter, suggesting that netrin-1 is a repellent for OP cells. Consistent with this, netrin-1 in the upper chamber increased the number of OP cells migrating through the filter, indicating that these cells preferentially migrate down a gradient of netrin-1. Interestingly, an equal concentration of netrin-1 in the top and bottom compartments reduced migration to a level similar to that produced by netrin-1 on the bottom alone. If netrin-1 produced a purely tropic effect on OP migration, it might be expected that surrounding the cells with a 

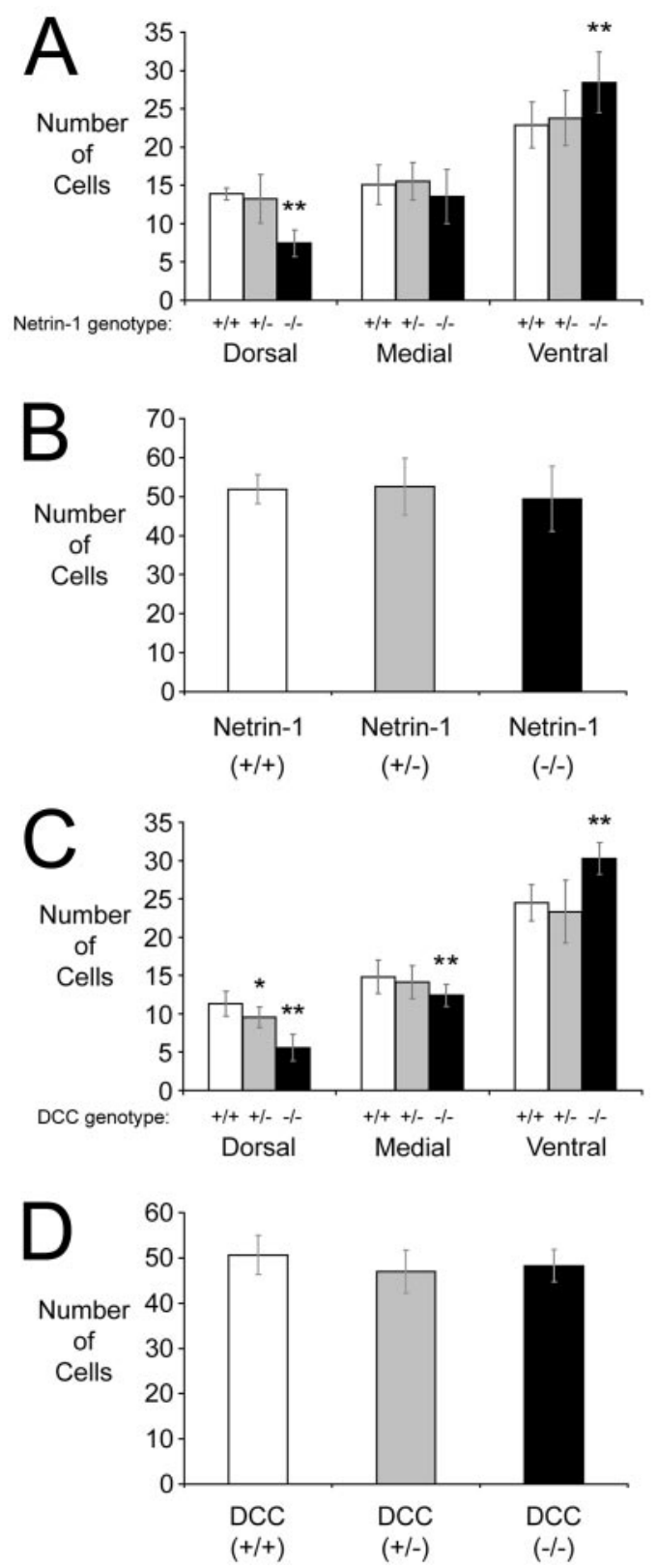

Figure 7. OP cell number is reduced in the dorsal spinal cord and increased in the ventral spinal cord of 15 mice lacking netrin- 1 or DCC function. A, C, Quantification of the number of OP cells in the dorsal, medial, and ventral thirds of the spinal cords of netrin-1 $(A)$ and DCC (C) wild-type, heterozygote, and homozygous loss-of-function embryos. As shown in Figure 5 , fewer OPs were detected in the dorsal spinal cords of the homozygous loss-of-function embryos, whereas a greater number of OPs were detected in the ventral spinal cords of these animals. $B, D$, Total number of OPs counted in the spinal cords of netrin-1 $(B)$ and DCC (D) wild-type, heterozygote, and mutant spinal cord sections. Values shown are means \pm SD. ${ }^{*} p<0.05 ;{ }^{* *} p<0.005$.

uniform concentration of netrin-1 would have no effect on motility. The observation that a uniform concentration of netrin-1 causes the cells to become less motile indicates that netrin also exerts a kinetic effect on OP motility. However, when netrin-1 is placed only in the upper compartment and a high concentration of netrin-1 surrounds the cells, the cells do not freeze, but given the opportunity to escape from netrin-1, they migrate to the lower side of the filter. These results show that netrin-1 inhibits OP motility, but also suggest that if an OP cell finds itself in the midst of a gradient of netrin-1, its movement will be asymmetri- cally inhibited, and the cell will move in the direction of less inhibition.

These findings suggest that asymmetric limited collapse of the OP cytoskeleton and withdrawal of OP cell processes may underlie the repellent response of OP cells to a gradient of netrin-1. Partial collapse has been proposed as a mechanism underlying turns made by axonal growth cones in response to repellent guidance cues. For example, semaphorins were first identified in vertebrates on the basis of their ability to cause growth cone collapse (Luo et al., 1993). Although a repellent cue can cause the complete collapse of a neuronal growth cone (Luo et al., 1993), encountering a local source of the same repellent, such as a microscopic bead coated with the cue, may only induce partial collapse (Fan and Raper, 1995). In this case, the edge of the growth cone contacting the bead may withdraw, but the growth cone will continue to extend away from the cue (Luo and Raper, 1994). Our demonstration that netrin-1 induces a rapid and persistent retraction of OP cell processes is consistent with the hypothesis that a gradient of netrin-1 may direct OP cell migration by triggering asymmetric collapse of the OP cytoskeleton.

In the chemotaxis assay, although migration toward netrin-1 is significantly reduced when compared with controls, migration was not completely blocked. Our findings are consistent with a model in which netrin-1 reduces but does not completely suppress spontaneous oligodendrocyte motility. If a cell is to move from a high concentration toward a lower concentration of a repellent cue, the collapsing action of the cue cannot be so potent that it inhibits motility entirely; otherwise the cell will never escape the high concentration of the cue. This interpretation is in agreement with the observations that netrin-1 induces partial but not complete withdrawal of OP cell processes, that netrin-1 does not completely block OP migration in the transfilter assay, and that a uniform concentration of netrin-1 presented on the top and bottom of the chemotaxis chamber inhibits migration to an extent similar to presentation of netrin- 1 in the bottom chamber alone.

\section{Oligodendrocytes but not oligodendrocyte precursors express netrin-1 in vivo}

Here we show that netrin-1 is not expressed by OP cells. We have reported recently that netrin-1 is expressed by myelinating oligodendrocytes in the adult mammalian spinal cord (Manitt et al., 2001). Whereas OPs are capable of migrating great distances and remyelinating axons when transplanted into either demyelinated lesions or mutant animals lacking normal myelination (Gumpel et al., 1989; Groves et al., 1993; Warrington et al., 1993), OPs transplanted into appropriately myelinated regions migrate very little (O'Leary and Blakemore, 1997). Furthermore, in a study using coculture of oligodendroglia and the CG4 OP-like cell line (Louis et al., 1992), the extending processes of CG4 cells collapsed when they contacted oligodendrocyte processes (Jefferson et al., 1997). These findings suggest that netrin-1 produced by mature oligodendroglia in vivo may inhibit the migration of OPs into regions in which sufficient numbers of oligodendrocytes are present and locally contribute to appropriately spacing them along the axon.

Myelination is essential for proper CNS function. In demyelinating diseases such as multiple sclerosis, even focal myelin loss can result in impairment (Orentas and Miller, 1998). The evidence presented here indicates that netrin-1 is an essential cue that directs migrating OP cells during neural development. Further understanding the fundamental mechanisms that direct the development and maturation of oligodendrocytes will provide 
insight into developing strategies that aim to promote remyelination in the context of demyelinating diseases.

\section{References}

Ackerman SL, Kozak LP, Przyborski SA, Rund LA, Boyer BB, Knowles BB (1997) The mouse rostral cerebellar malformation gene encodes an UNC-5-like protein. Nature 386:838-842.

Alcantara S, Ruiz M, De Castro F, Soriano E, Sotelo C (2000) Netrin 1 acts as an attractive or as a repulsive cue for distinct migrating neurons during the development of the cerebellar system. Development 127:1359-1372.

Armstrong RC (1998) Isolation and characterization of immature oligodendrocyte lineage cells. Methods 16:282-292.

Armstrong RC, Harvath L, Dubois-Dalcq ME (1990) Type 1 astrocytes and oligodendrocyte-type 2 astrocyte glial progenitors migrate toward distinct molecules. J Neurosci Res 27:400-407.

Calver AR, Hall AC, Yu WP, Walsh FS, Heath JK, Betsholtz C, Richardson WD (1998) Oligodendrocyte population dynamics and the role of PDGF in vivo. Neuron 20:869-882.

Colamarino SA, Tessier-Lavigne M (1995) The axonal chemoattractant netrin-1 is also a chemorepellent for trochlear motor axons. Cell 81:621-629.

Colavita A, Culotti JG (1998) Suppressors of ectopic UNC-5 growth cone steering identify eight genes involved in axon guidance in Caenorhabditis elegans. Dev Biol 194:72-85.

Deiner MS, Kennedy TE, Fazeli A, Serafini T, Tessier-Lavigne M, Sretavan DW (1997) Netrin-1 and DCC mediate axon guidance locally at the optic disc: loss of function leads to optic nerve hypoplasia. Neuron 19:575-589.

Denizot F, Lang R (1986) Rapid colorimetric assay for cell growth and survival. Modifications to the tetrazolium dye procedure giving improved sensitivity and reliability. J Immunol Methods 89:271-277.

Diers-Fenger M, Kirchhoff F, Kettenmann H, Levine JM, Trotter J (2001) AN2/NG2 protein-expressing glial progenitor cells in the murine CNS: isolation, differentiation, and association with radial glia. Glia 34:213-228.

Falk W, Goodwin Jr RH, Leonard EJ (1980) A 48-well micro chemotaxis assembly for rapid and accurate measurement of leukocyte migration. J Immunol Methods 33:239-247.

Fan J, Raper JA (1995) Localized collapsing cues can steer growth cones without inducing their full collapse. Neuron 14:263-274.

Foran DR, Peterson AC (1992) Myelin acquisition in the central nervous system of the mouse revealed by an MBP-LacZ transgene. J Neurosci 12:4890-4897.

Forcet C, Ye X, Granger L, Corset V, Shin H, Bredesen DE, Mehlen P (2001) The dependence receptor DCC (deleted in colorectal cancer) defines an alternative mechanism for caspase activation. Proc Natl Acad Sci USA 98:3416-3421.

Frost EE, Milner R, ffrench-Constant C (2000) Migration assays for oligodendrocyte precursor cells. Methods Mol Biol 139:265-278.

Fruttiger M, Karlsson L, Hall AC, Abramsson A, Calver AR, Bostrom H, Willetts K, Bertold CH, Heath JK, Betsholtz C, Richardson WD (1999) Defective oligodendrocyte development and severe hypomyelination in PDGF-A knockout mice. Development 126:457-467.

Fu H, Qi Y, Tan M, Cai J, Takebayashi H, Nakafuku M, Richardson W, Qiu M (2002) Dual origin of spinal oligodendrocyte progenitors and evidence for the cooperative role of Olig2 and Nkx2.2 in the control of oligodendrocyte differentiation. Development 129:681-693.

Garcion E, Faissner A, ffrench-Constant C (2001) Knockout mice reveal a contribution of the extracellular matrix molecule tenascin- $C$ to neural precursor proliferation and migration. Development 128:2485-2496.

Goldowitz D, Hamre KM, Przyborski SA, Ackerman SL (2000) Granule cells and cerebellar boundaries: analysis of Unc5h3 mutant chimeras. J Neurosci 20:4129-4137.

Groves AK, Barnett SC, Franklin RJ, Crang AJ, Mayer M, Blakemore WF, Noble M (1993) Repair of demyelinated lesions by transplantation of purified O-2A progenitor cells. Nature 362:453-455.

Gumpel M, Gout O, Lubetzki C, Gansmuller A, Baumann N (1989) Myelination and remyelination in the central nervous system by transplanted oligodendrocytes using the shiverer model. Discussion on the remyelinating cell population in adult mammals. Dev Neurosci 11:132-139.

Hajihosseini M, Tham TN, Dubois-Dalcq M (1996) Origin of oligodendrocytes within the human spinal cord. J Neurosci 16:7981-7994.
Hamasaki T, Goto S, Nishikawa S, Ushio Y (2001) A role of netrin-1 in the formation of the subcortical structure striatum: repulsive action on the migration of late-born striatal neurons. J Neurosci 21:4272-4280.

Hamelin M, Zhou Y, Su MW, Scott IM, Culotti JG (1993) Expression of the UNC-5 guidance receptor in the touch neurons of C. elegans steers their axons dorsally. Nature 364:327-330.

Hedgecock EM, Culotti JG, Hall DH (1990) The unc-5, unc-6, and unc-40 genes guide circumferential migrations of pioneer axons and mesodermal cells on the epidermis in C. elegans. Neuron 4:61-85.

Hong K, Hinck L, Nishiyama M, Poo MM, Tessier-Lavigne M, Stein E (1999) A ligand-gated association between cytoplasmic domains of UNC5 and DCC family receptors converts netrin-induced growth cone attraction to repulsion. Cell 97:927-941.

Hopker VH, Shewan D, Tessier-Lavigne M, Poo M, Holt C (1999) Growthcone attraction to netrin-1 is converted to repulsion by laminin-1. Nature 401:69-73.

Jefferson S, Jacques T, Kiernan BW, Scott-Drew S, Milner R, ffrenchConstant C (1997) Inhibition of oligodendrocyte precursor motility by oligodendrocyte processes: implications for transplantation-based approaches to multiple sclerosis. Mult Scler 3:162-167.

Keino-Masu K, Masu M, Hinck L, Leonardo ED, Chan SS, Culotti JG, TessierLavigne M (1996) Deleted in Colorectal Cancer (DCC) encodes a netrin receptor. Cell 87:175-185.

Keleman K, Dickson BJ (2001) Short- and long-range repulsion by the Drosophila Unc5 netrin receptor. Neuron 32:605-617.

Kennedy TE, Serafini T, de la Torre JR, Tessier-Lavigne M (1994) Netrins are diffusible chemotropic factors for commissural axons in the embryonic spinal cord. Cell 78:425-435.

Kiernan BW, Gotz B, Faissner A, ffrench-Constant C (1996) Tenascin-C inhibits oligodendrocyte precursor cell migration by both adhesiondependent and adhesion-independent mechanisms. Mol Cell Neurosci 7:322-335.

Leonardo ED, Hinck L, Masu M, Keino-Masu K, Ackerman SL, TessierLavigne M (1997) Vertebrate homologues of C. elegans UNC-5 are candidate netrin receptors. Nature 386:833-838.

Llambi F, Causeret F, Bloch-Gallego E, Mehlen P (2001) Netrin-1 acts as a survival factor via its receptors UNC5H and DCC. EMBO J 20:2715-2722.

Louis JC, Magal E, Muir D, Manthorpe M, Varon S (1992) CG-4, a new bipotential glial cell line from rat brain, is capable of differentiating in vitro into either mature oligodendrocytes or type- 2 astrocytes. J Neurosci Res 31:193-204.

Luo Y, Raper JA (1994) Inhibitory factors controlling growth cone motility and guidance. Curr Opin Neurobiol 4:648-654.

Luo Y, Raible D, Raper JA (1993) Collapsin: a protein in brain that induces the collapse and paralysis of neuronal growth cones. Cell 75:217-227.

Manitt C, Colicos MA, Thompson KM, Rousselle E, Peterson AC, Kennedy TE (2001) Widespread expression of netrin-1 by neurons and oligodendrocytes in the adult mammalian spinal cord. J Neurosci 21:3911-3922.

Mehlen P, Rabizadeh S, Snipas SJ, Assa-Munt N, Salvesen GS, Bredesen DE (1998) The DCC gene product induces apoptosis by a mechanism requiring receptor proteolysis. Nature 395:801-804.

Miller RH (1996) Oligodendrocyte origins. Trends Neurosci 19:92-96.

Miller RH, Payne J, Milner L, Zhang H, Orentas DM (1997) Spinal cord oligodendrocytes develop from a limited number of migratory highly proliferative precursors. J Neurosci Res 50:157-168.

Milner R, Edwards G, Streuli C, ffrench-Constant C (1996) A role in migration for the $\alpha \mathrm{V} \beta 1$ integrin expressed on oligodendrocyte precursors. J Neurosci 16:7240-7252.

Noble M, Murray K, Stroobant P, Waterfield MD, Riddle P (1988) Plateletderived growth factor promotes division and motility and inhibits premature differentiation of the oligodendrocyte/type-2 astrocyte progenitor cell. Nature 333:560-562.

O'Leary MT, Blakemore WF (1997) Oligodendrocyte precursors survive poorly and do not migrate following transplantation into the normal adult central nervous system. J Neurosci Res 48:159-167.

Ono K, Bansal R, Payne J, Rutishauser U, Miller RH (1995) Early development and dispersal of oligodendrocyte precursors in the embryonic chick spinal cord. Development 121:1743-1754.

Orentas DM, Miller RH (1996) The origin of spinal cord oligodendrocytes is dependent on local influences from the notochord. Dev Biol 177:43-53.

Orentas DM, Miller RH (1998) Regulation of oligodendrocyte development. Mol Neurobiol 18:247-259. 
Pang Y, Cai Z, Rhodes PG (2000) Effects of lipopolysaccharide on oligodendrocyte progenitor cells are mediated by astrocytes and microglia. J Neurosci Res 62:510-520.

Pringle NP, Richardson WD (1993) A singularity of PDGF $\alpha$-receptor expression in the dorsoventral axis of the neural tube may define the origin of the oligodendrocyte lineage. Development 117:525-533.

Przyborski SA, Knowles BB, Ackerman SL (1998) Embryonic phenotype of Unc5h3 mutant mice suggests chemorepulsion during the formation of the rostral cerebellar boundary. Development 125:41-50.

Raff MC, Miller RH, Noble M (1983) A glial progenitor cell that develops in vitro into an astrocyte or an oligodendrocyte depending on culture medium. Nature 303:390-396.

Richter-Landsberg C, Vollgraf U (1998) Mode of cell injury and death after hydrogen peroxide exposure in cultured oligodendroglia cells. Exp Cell Res 244:218-229.

Serafini T, Colamarino SA, Leonardo ED, Wang H, Beddington R, Skarnes WC, Tessier-Lavigne M (1996) Netrin-1 is required for commissural axon guidance in the developing vertebrate nervous system. Cell 87:1001-1014.

Simpson PB, Armstrong RC (1999) Intracellular signals and cytoskeletal elements involved in oligodendrocyte progenitor migration. Glia 26:22-35.

Spassky N, Goujet-Zalc C, Parmantier E, Olivier C, Martinez S, Ivanova A,
Ikenaka K, Macklin W, Cerruti I, Zalc B, Thomas JL (1998) Multiple restricted origin of oligodendrocytes. J Neurosci 18:8331-8343.

Spassky N, De Castro F, Le Bras B, Heydon K, Queraud-LeSaux F, BlochGallego E, Chedotal A, Zalc B, Thomas JL (2002) Directional guidance of oligodendroglial migration by class 3 semaphorins and netrin-1. J Neurosci 22:5992-6004.

Stallcup WB, Beasley L (1987) Bipotential glial precursor cells of the optic nerve express the NG2 proteoglycan. J Neurosci 7:2737-2744.

Sugimoto Y, Taniguchi M, Yagi T, Akagi Y, Nojyo Y, Tamamaki N (2001) Guidance of glial precursor cell migration by secreted cues in the developing optic nerve. Development 128:3321-3330.

Varela-Echavarria A, Tucker A, Puschel AW, Guthrie S (1997) Motor axon subpopulations respond differentially to the chemorepellents netrin-1 and semaphorin D. Neuron 18:193-207.

Warrington AE, Barbarese E, Pfeiffer SE (1993) Differential myelinogenic capacity of specific developmental stages of the oligodendrocyte lineage upon transplantation into hypomyelinating hosts. J Neurosci Res 34:1-13.

Yu WP, Collarini EJ, Pringle NP, Richardson WD (1994) Embryonic expression of myelin genes: evidence for a focal source of oligodendrocyte precursors in the ventricular zone of the neural tube. Neuron 12:13531362. 